\title{
Impact of the omic technologies for understanding the modes of action of biological control agents against plant pathogens
}

\author{
Sebastien Massart • Michele Perazzolli • \\ Monica Höfte · Ilaria Pertot • M. Haïssam Jijakli
}

Received: 25 March 2015/Accepted: 3 July 2015/Published online: 10 July 2015

(C) International Organization for Biological Control (IOBC) 2015

\begin{abstract}
The characterization of microbial biological control agents (MBCAs) is crucial to improve their efficacy and consistency as biopesticides. Powerful approaches to characterize MBCA's modes of action are provided by modern molecular technologies. This paper reviews improvements achieved in this subject by three "omics" approaches: namely the genomic, the transcriptomic and the proteomic approaches. The paper discusses the advantages and drawbacks of new molecular techniques and 'discovery driven' approaches to the study of the biocontrol properties against plant pathogens. Omics technologies are capable of: (i) identifying the genome,
\end{abstract}

Handling Editor: Jesus Mercado Blanco.

S. Massart ( $\square) \cdot$ M. H. Jijakli

Laboratory of Integrated and Urban Phytopathology, Gembloux Agro-Bio Tech, University of Liège, Passage des déportés, 2 - 5030 Gembloux, Belgium

e-mail: sebastien.massart@ulg.ac.be

M. Perazzolli · I. Pertot

Research and Innovation Centre, Fondazione Edmund

Mach (FEM), Via E. Mach 1,

38010 San Michele all'Adige, Italy

M. Höfte

Laboratory of Phytopathology, Fac. Bioscience

Engineering, Ghent University, Coupure Links 653,

9000 Ghent, Belgium transcriptome or proteome features of an MBCA strain, (ii) comparing properties of strains/mutants with different biocontrol efficacy, (iii) identifying and characterizing genes, mRNAs and proteins involved in MBCA modes of action, and (iv) simultaneously studying the transcriptome or proteome of the plant host, the plant pathogen and the MBCAs in relation to their bi- or tri-trophic interactions.

Keywords Biological control · Omics · Genomics · Transcriptomics $\cdot$ Proteomics $\cdot$ Biocontrol agent

\section{Introduction}

Biological control agents (BCAs) have generated great enthusiasm as safe and sustainable plant protection tools. Microbial BCAs (MBCAs) have been developed as active ingredients of several biopesticides. However, the practical application of MBCAs as biofungicides is hampered by their inconsistent efficacy compared with synthetic chemical compounds. MBCAs have four main modes of action against plant pathogens: competition for space and/or nutrients, antibiosis, hyperparasitism and the induction of host resistance. Understanding how an MBCA acts can greatly improve its efficacy and consistency in practical use as a biofungicide and helps researchers to select the best strains. Such information can assist the grower in optimizing the method and timing of application. Understanding how the MBCA acts can 
also help in the designing of the most appropriate formulation for further improving efficacy and consistency. The description of the mode of action is also required for registration under EU regulations (Reg. EC No. 1007/2009).

A large variety of methodologies can be used to decipher the mode of action of a BCA. Microbiological methods are traditionally the first approach. These can be used to assess the production of antibiotics or toxic metabolites for example by the MBCAs against the pathogen with in vitro co-cultivation or the correlation between the dose (CFU) of the applied MBCAs and its efficacy. Biochemical studies have also been extensively used in the past to identify proteins (Grevesse et al. 2003; Jijakli and Lepoivre 1998) and metabolites (Puopolo et al. 2014) secreted by the MBCA that have a direct impact on the pathogen.

Over the past decade the development of molecular techniques, i.e. microarrays, high throughput sequencing and large-scale proteomics, have introduced new tools for the understanding of the mechanisms underlying the biocontrol properties of MBCAs against plant pathogens. These techniques, as applied to fungal BCAs, were reviewed by Massart and Jijakli (2007). This paper aims to critically summarize the latest improvements and to review applications of these new technologies to the study of MBCAs, particularly in terms of biocontrol in relation to plant pathogens and what their mechanisms of action are in this regard. It is important to mention also that metabolomic technologies have also contributed to the study of MBCAs but are not addressed in this review.

\section{Genome sequencing of biocontrol agents}

The bacterial strain Pseudomonas protegens Pf5 was the first MBCA whose genome was fully sequenced by Sanger sequencing (Paulsen et al. 2005). By using the same technology the genome of Bacillus amyloliquefaciens FBZ42 was also sequenced two years later (Chen et al. 2007). The rise and availability of high throughput sequencing (also called next generation sequencing, NGS) techniques, reviewed elsewhere (Knief 2014), has greatly accelerated the sequencing of microbial genomes. The sequencing throughput evolution has been exponential, making NGS analysis more affordable for MBCAs. Among the 27 published prokaryotic genomes of MBCA only eight have the complete genome sequenced (Table 1). If the circular chromosome of a microbial strain has not been entirely sequenced and closed, the genome sequence is called a 'draft genome' and corresponds to a list of sequences, contigs and scaffolds. The quality of a draft genome may vary considerably (Table 1) and can be evaluated through the number of contigs (the less the better) and the annotation (automated vs. manually curated). Closing a genome has clear advantages as then the complete gene composition is known, but it is a time- and resource-consuming process. A draft genome sequence of good quality is in fact sufficient for an overview of the genes and pathways of the strain and requires relatively limited effort and cost. The two main drawbacks of a draft genome are that a part of the genome is not sequenced so some genes or important mutations could be missed, and the relative position of the contigs or scaffolds is also unknown. The interpretation of a draft genome must therefore take into account these specifics and lacunae.

The majority of sequenced MBCAs are bacteria (Table 1). For eukaryotic MBCAs, only four genomes have been published so far. In 2011, the genome sequence of Trichoderma atroviride and $T$. virens were sequenced and compared to the genome of $T$. reesei (Kubicek et al. 2011). The genome sequence of T. hamatum GD12 has been published more recently (Studholme et al. 2013). The consequences derived from the availability of multiple genome sequences of Trichoderma species have been analyzed in depth elsewhere (Mukherjee et al. 2013). Pseudozyma flocculosa DAOM 196992 (Lefebvre et al. 2013) is the fourth sequenced eukaryotic MBCA.

The genome availability allows high-throughput analyses which can speed up the study of the biocontrol properties by (i) identifying genome features of the strain, (ii) identifying and characterizing genes potentially involved in biocontrol properties, (iii) characterizing gene clusters with unknown functions (genome mining), (iv) comparing the genome with other strains from the same species (with or without biocontrol properties) or from related species (comparative genomics) and (v) permitting the study of gene transcription in a holistic manner instead of by means of gene targeted studies.

The annotation process identifies specific genome features of the MBCA strain, such as gene clusters, mobile or repetitive elements and prophage 


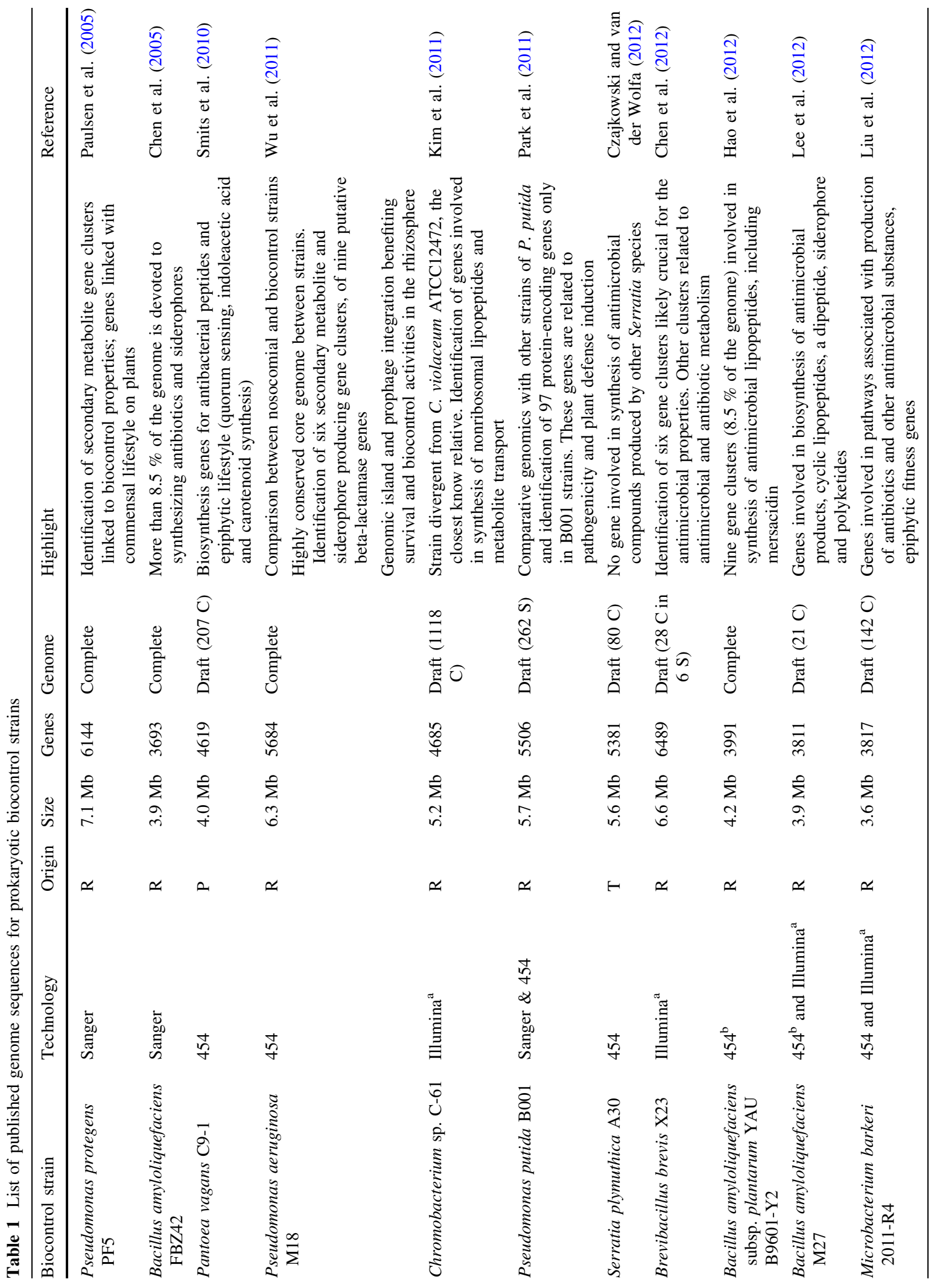




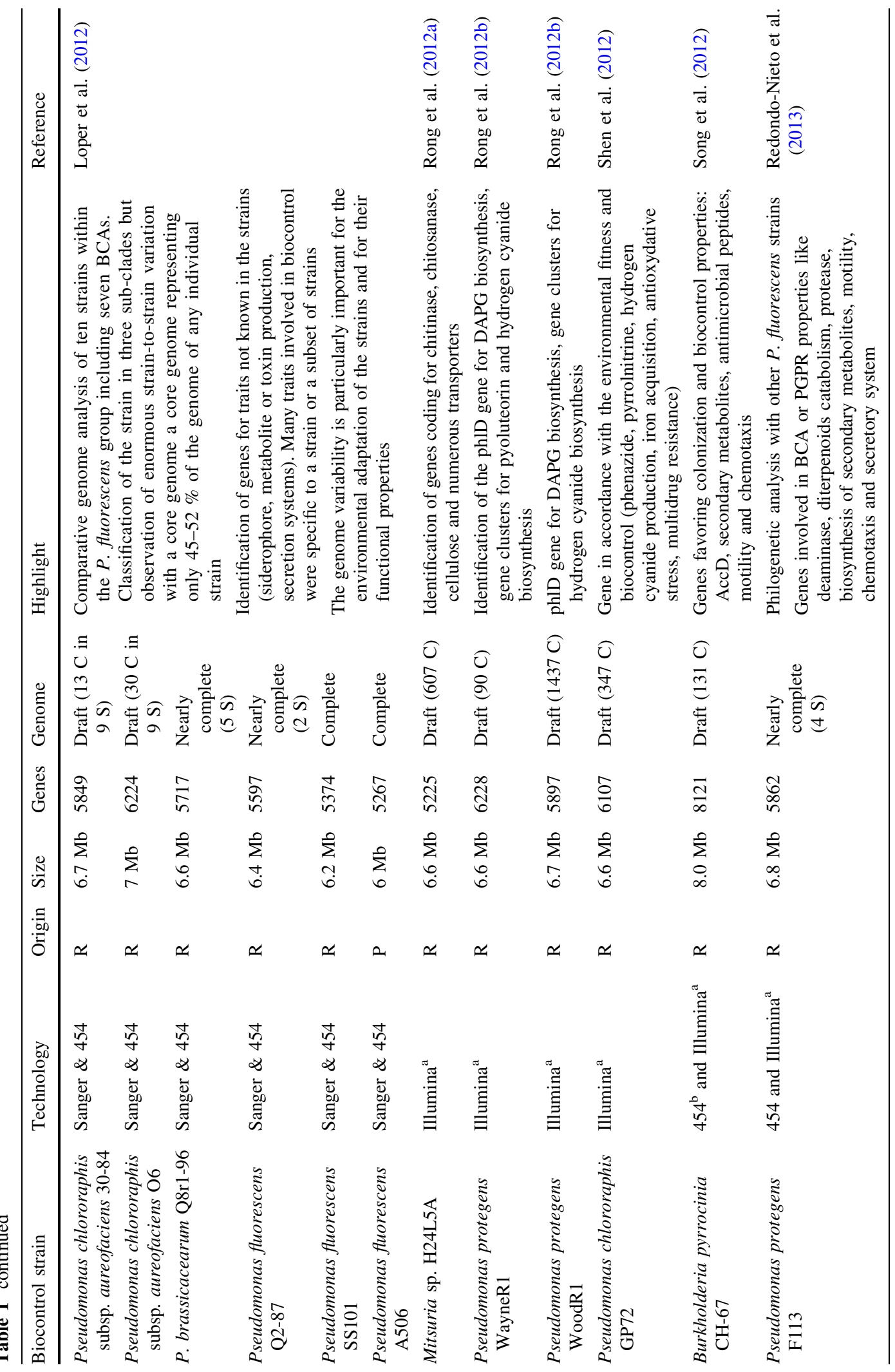




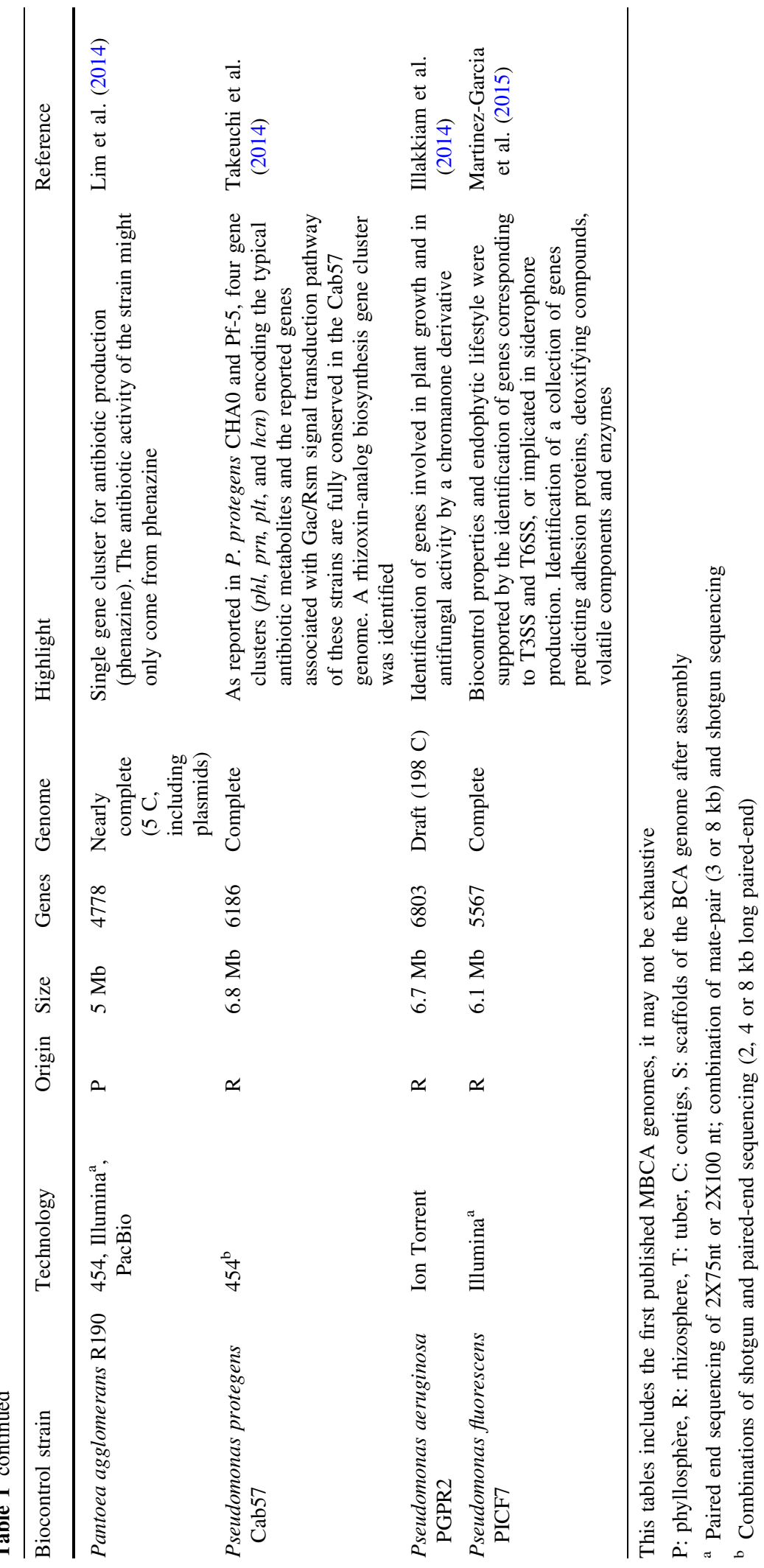


integration for bacteria, and plasmids. Importantly, the annotation process also assigns a function to a variable proportion of the identified gene clusters. The remaining gene clusters are considered as gene candidates whose functions are not known.

The interpretation of the genome and the characterized genes of the MBCA is greatly improved by a preliminary understanding of the modes of action of the strain using traditional microbiological methods. Thousands of genes will indeed be identified in the genome and the most interesting ones need to be selected for in depth studies. This knowledge will then drive 'in depth pathway analysis'. For example, the genome of a MBCA acting by mycoparasitism is scanned for the presence of secretion systems and extracellular enzymes degrading fungal cell walls. Genes involved in the production of primary or secondary metabolites are targeted in a BCA acting by antibiosis. The genes and pathways under study can vary between MBCA strains and their modes of action (Table 1). So, even if genome sequencing can reveal new pathways involved in biocontrol properties, the information gained from genome sequencing can be leveraged and its interpretation guided by previous extensive microbiological and biochemical evaluation of MBCA properties.

Another important focus in the analysis of the MBCA's genome sequence is the identification of genes and pathways linked to the interaction with plants and in the adaptation of the MBCA to the environment (competition for space and nutrients). Such genes can for example be identified by comparison with plant-pathogen interaction pathways described in the KEGG database (Kanehisa et al. 2002) or by comparative genomics with other bacteria isolated from the rhizosphere or endosphere of plants. These bacteria are, for example, plant growth promoting rhizobacteria (Mathimaran et al. 2012; Niu et al. 2011) or plant pathogens or commensal bacteria (Brown et al. 2012). The genome sequence also enables identification of high level of redundancy for functions that are important in terms of the biocontrol properties, as chitinase genes in genomes of the Trichoderma species (Mukherjee et al. 2013).

Comparative genomics is also frequently used to identify pathways or mutations that are specific to MBCAs. Comparative genomics involves the comparison of genomic features between the genomes of different organisms (strains within a species, and/or taxonomically or ecologically related species). The output of this analysis is greatly dependent on the genome sequence availability in the databases. The best case is indeed a seminal work of comparative genomics on ten strains of $P$. fluorescens group, including seven MBCA strains (Loper et al. 2012). The overall results showed a very variable genome and enormous differences between strains (Table 1). The work also provided better understanding of the genetic variability between BCA strains and of the variety of genes and pathways used in biocontrol, many of them specific to a single strain (Loper et al. 2012). This opened new research opportunities for further improvements in practical usage of BCA strains and for identification of new metabolites through genome mining.

Comparisons with phylogenetically distant species may identify some false positive genes not involved in MBCA properties. For example, Liu et al. (2012) underlined the difficulties in predicting biocontrol functions for many genes in the BCA strain Microbacterium barkeri $2011-\mathrm{R} 4$ as there were at that time only two genomes available for the genus Microbacterium. On the other hand the B. amyloliquefaciens FBZ42 genome was compared with the genome of $B$. subtilis to reveal an unexpected potential for the production of secondary metabolites with more than $8.5 \%$ of the genome devoted to antibiotics and siderophore synthesis by non-ribosomal pathways (Chen et al. 2007).

Comparative genomic analysis can also be carried out to compare MBCAs with the genomes of pathogens. The comparison between a plant pathogen and a closely related BCA provided new insights into subtle genetic differences between their lifestyles. The $P$. fluorescens group, including MBCA and pathogen strains, is particularly interesting for such comparison. For example, the identification of similar secondary metabolites production in both biocontrol and pathogen strains warrants further investigation into biocontrol properties through ongoing genome mining on new orphan biosynthetic cluster genes in biocontrol strains (Eyiwumi Olorunleke et al. 2015).

The candidate genes and uncharacterized regions can be studied by genome mining. Genome mining consists in the discovery of new natural products from sequenced microbes by genomics-guided approaches and is particularly well developed for bacteria. Several approaches have been developed to discover metabolic products of biosynthetic gene clusters and some 
have been synthetized (Bachmann et al. 2014; Challis 2008). For MBCAs, genome mining strategies have been extensively applied for the P. fluorescens group, mainly to identify polyketide synthase (PKS) and nonribosomal peptide synthetase (NRPS), unraveling new antibiotic products (Eyiwumi Olorunleke et al. 2015).

Finally, the genome sequence of an MBCA can also help in the registration process for a plant protection product. For example, Wu et al. (2011) identified the genomic differences between the MBCA $P$. aeruginosa M18 and certain $P$. aeruginosa strains, which are human pathogens. They underlined the genetic distance and the lack of genes involved in human pathogenicity in the MBCA strain, prerequisites for any plant protection product registration.

\section{Transcriptomic studies of biocontrol agents}

Historically, transcriptomic studies on MBCAs were carried out with a targeted approach on candidate genes, for example through real-time RT-PCR. The gene selection was based on microbiological, histochemical or biochemical observations. For fungal biocontrol agents, the genes involved in pathogen cell wall degradation (glucanases, chitinases, proteases, etc.) were extensively studied with this approach (Massart and Jijakli 2007). The genes involved in secondary metabolite production were mostly studied in relation to bacterial BCAs. This approach, based on a priori hypotheses, provided better understanding of the gene expression for the studied genes but lacked comprehensive analysis of the transcriptome. To overcome this limitation, 'discovery driven' methods were developed (Liu and Yang 2005; Massart and Jijakli 2006; Viterbo et al. 2004) to identify without a priori genes with a differential transcription under contrasting conditions.

Until a decade ago, the targeted and 'discovery driven' approaches were clearly distinct, even if realtime PCR was frequently used to confirm the differential expression of genes identified by the 'discovery driven' approach. The emergence of microarrays and other high throughput technologies led to the convergence of targeted and 'discovery driven' approaches. Currently, standard microarrays are available for the study of the transcriptome of many host plants and custom microarrays can be designed for any MBCA with a sequenced and annotated genome or cDNA sequences. Bioinformatic analyses of microarray data requires specific biostatistics knowledge but is now standardized and considered to be user-friendly; see De Las et al. (2014) for an extended review. The microarray has been progressively superseded by RNA sequencing which has several advantages over microarray. These include high resolution, a better dynamic range of detection, lower technical variations and transcript-level analysis instead of gene-level analysis (McGettigan 2013; Nookaew et al. 2012). Interestingly, RNA sequencing only requires small technical adaptations to be able to simultaneously study the transcriptome of the host plant, the plant pathogen and the MBCAs in their tri-trophic interactions. With the growth of high-throughput technologies, data analysis is becoming a key and limiting factor requiring specific knowledge and training. However, improvements in computational power, the simplification of the analysis and of the parameterization through freely available or commercial software are facilitating the manipulation and analysis of the generated sequences and should steadily speed up and simplify the spread of RNA sequencing.

Large-scale transcriptomic studies carried out with MBCAs are summarized in Table 2. The summary shows key elements for transcriptome analysis and future research directions that should be taken in relation to MBCAs. The MBCA transcriptome studies have been particularly useful in terms of providing a better understanding of how these MBCAs act and of the complex gene regulation sustaining the effect of the MBCA on the pathogenesis. More specifically the results highlighted genes involved in niche adaptation, competition for nutrients and space (Adomas et al. 2006; Wu et al. 2011), the complex interplay and synchronization of gene transcription needed for efficient mycoparasitism (Reithner et al. 2011) and the more comprehensive understanding of the cell physiology sustaining mycoparasitism (Seidl et al. 2009) or the kinetics of MBCA-pathogen interactions (Barret et al. 2009a, b). The plant transcriptome studies have identified the plant defense pathways stimulated by the MBCA against the plant pathogen. An important range of pathways can be upregulated in presence of an MBCA, such as jasmonic acid (Okubara et al. 2010; Sun et al. 2011), abscisic acid (Feng et al. 2012), PR proteins (Okubara et al. 2010) and the responses to oxidative (Okubara et al. 2010; 


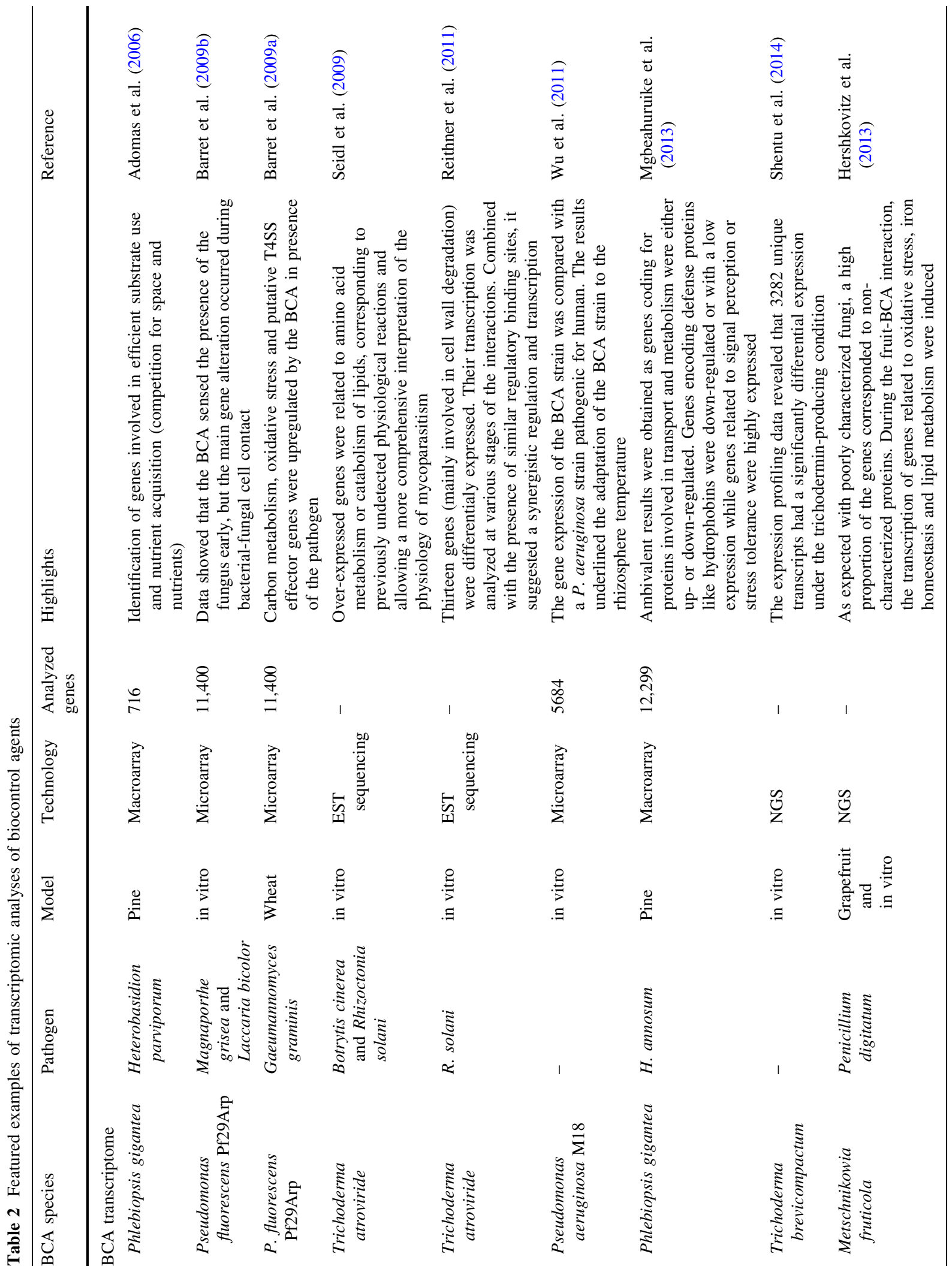




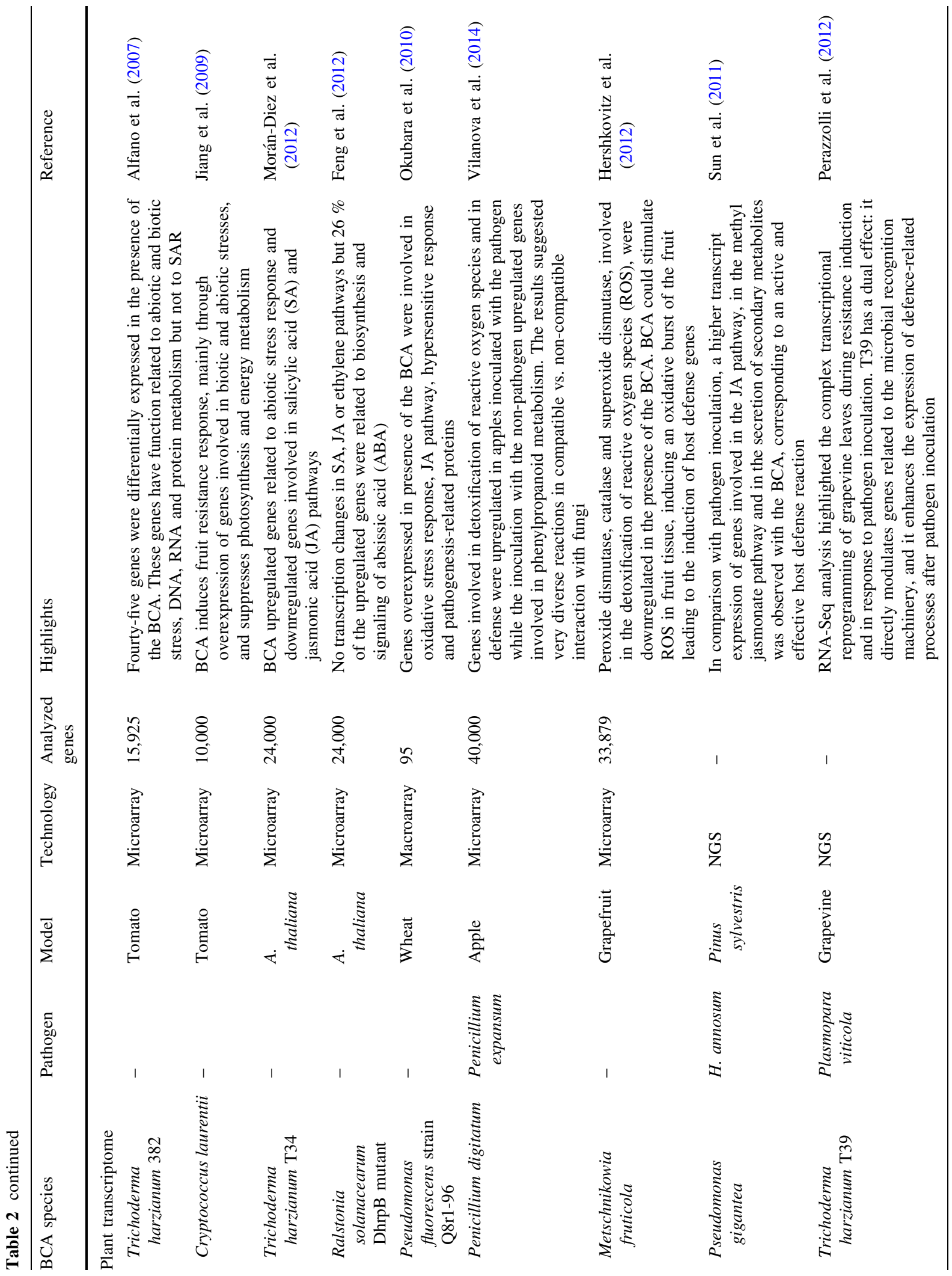


Vilanova et al. 2014) or biotic and abiotic stresses (Alfano et al. 2007; Jiang et al. 2009; Morán-Diez et al. 2012). The conclusions were nevertheless greatly dependent on the studied model. For example, $P$. fluorescens strain Q8r1-96 and P. gigantea upregulated the jasmonic acid pathways in wheat and Pinus sylvestris respectively (Okubara et al. 2010; Sun et al. 2011) while $T$. harzianum strain T34 downregulated that pathway in A. thaliana (Morán-Diez et al. 2012) and Ralstonia solanacearum DhrpB mutant did not modify it in the same plant model (Feng et al. 2012). Whatever the methodology used to identify the differentially expressed genes, it is essential to confirm the results of high throughput 'discovery driven' methodologies by an independent technique, such as real-time RT-PCR.

The growing availability of sequenced and annotated genomes will greatly facilitate the large-scale study of transcriptomes in the future whichever methods are used. It will in particular impact on the design of microarrays and data analyses of RNA sequencing. RNA sequencing can also improve the genome annotation by identifying new transcript variants or previously unknown genes.

A key element to the success of a gene expression study is the experimental model designed to identify the genes related to biocontrol activity. The majority of the studies have compared in vitro conditions using various carbon sources or by confrontation assays with the pathogen. These experiments are easy to carry out and to control but can produce biased results compared with in situ conditions. Gene expression studies with MBCAs have also been mainly focused on transcriptome analysis of a single species, either the MBCA, the host plant or the plant pathogen. Some pioneering experiments using classical real-time PCR (Daval et al. 2011) or microarray (Rubio et al. 2014) have shown the usefulness of these approaches for understanding the complex interplay between two or three species. The design and analysis of in situ models of bi- (plant-MBCA) or tri-trophic (plant-MBCA-pathogen) interactions should be preferred in the future and should survey the transcriptome of all the species.

Large-scale transcriptomics can also be applied to understand gene expression changes of the genetically transformed MBCA that exhibits modified biocontrol properties (Montero-Barrientos et al. 2011; Trushina et al. 2013). Comprehensive understanding of the gene 
function in cell biology and MBCA properties can thus be obtained.

Biological interpretation of the data can be puzzling. As an example, Mgbeahuruike et al. (2013) found different results according to the stage of growth or confrontation of the MBCA. This underlines the complexity of biocontrol mechanisms and the importance of finding an appropriate experimental design with suitable sample timing. Moreover, for eukaryotic MBCA and poorly annotated genomes, many differentially expressed genes do not have a known function, which limits any biological interpretation of their differential expression.

\section{Proteomic analyses of biocontrol agents}

The proteome is the entire protein complement expressed by a genome (Wilkins et al. 1995). Proteomics is thus defined as the qualitative (i.e. identification, function, post-translational modifications, etc.) and quantitative (i.e. abundance, distribution within different localizations, temporal changes in abundance, etc.) analysis of the proteins expressed by a genome in a specific tissue (Wilkins et al. 1995). Proteomic studies are essential for the characterization of the biocontrol process, since the final gene product responsible for the biocontrol properties (e.g. lytic enzymes and elicitors of plant resistance) can be directly identified.

The quantification of protein can be carried out with a 'targeted' approach, focusing on proteins selected a priori as known to be related to the biocontrol. A 'discovery driven' approach can also be used, investigating all proteins expressed during the biocontrol process, to identify new proteins involved and/or to obtain a global view on the mechanisms. In the targeted approach specific antibodies or enzymatic assays are frequently used to assess the level and the activity of enzymes related to biocontrol (e.g. chitinases, cellulases and proteases) (Aegerter and Gordon 2006). For the 'discovery driven' approach, several proteomic methodologies are available, they can be distinguished as the gel-based and the gel-free methods and excellent reviews recently discussed technological advances in the microbial proteomics (Armengaud 2013; Gil and Monteoliva 2014; Otto et al. 2014, 2012; Oudenhove and Devreese 2013). Briefly, the gel-based approaches are based on protein separation by the two-dimensional (2D) gel electrophoresis followed by protein spot isolation and identification by mass spectrometry, while the gel-free proteomics is based on the enzymatic digestion of the protein mixture followed by liquid chromatography and identification of peptide sequences by mass spectrometry (Otto et al. 2012; Wöhlbrand et al. 2013). Although the greater part of biocontrol proteomics studies were carried out using the more traditional gel-based methods (Table 3), these approaches are subjected to the limitation of scarce reproducibility and limited numbers of samples and proteins that can be analyzed for each experiment. The gel-free mass spectrometry-based methods have revolutionized proteomic studies on MBCAs in terms of comprehensiveness, sensitivity and versatility (Brotman et al. 2008; Kwasiborski et al. 2014; Lim et al. 2012; Palmieri et al. 2012). In particular, they enabled and improved analysis of proteins previously excluded from the gel-based detection for their physical and chemical properties (Otto et al. 2012). Liquid chromatography mass spectrometry (LC-MS) analyses are beginning to be of widespread application for MBCA studies. Labeling procedures quantify changes of protein abundance between samples and at the same time detect post-translational modifications (Otto et al. 2012; Wöhlbrand et al. 2013). Efficient label-free protocols for relative quantification based on LC-MS methods are available (Otto et al. 2012), and a statistical model for comparative proteomics studies has been optimized on T. reesei data (Daly et al. 2008). High throughput analyses of proteomes are nowadays possible thanks to new mass spectrometers that permit sequencing of thousands of protein reads, and association with the specific protein that originated each peptide in the mixtures (Helsens et al. 2010) can be made using powerful bioinformatic tools for protein identification (Mesuere et al. 2012). Even if gel-based techniques still remain pivotal for routine analysis (Otto et al. 2012), the high-throughput gel-free peptide isolation followed by tandem mass spectrometry technology make 2D gel electrophoresis approaches obsolete (Wöhlbrand et al. 2013).

Proteomics have been applied to the study of biocontrol features of MBCAs (i) to obtain the proteomic fingerprint of the strain and/or to understand basic biological responses, (ii) to identify differentially expressed proteins related to the biocontrol processes, and (iii) to identify proteins with 


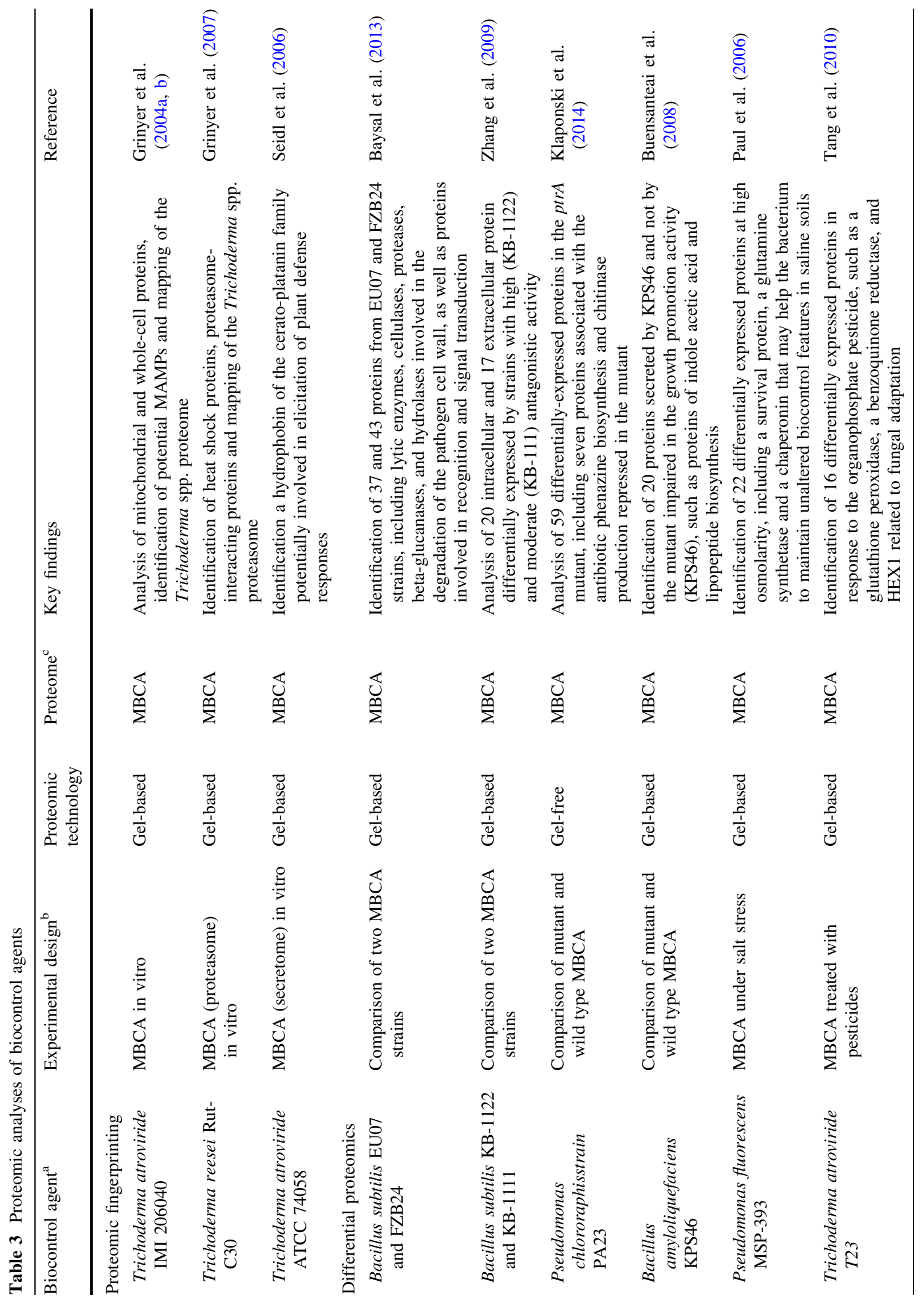




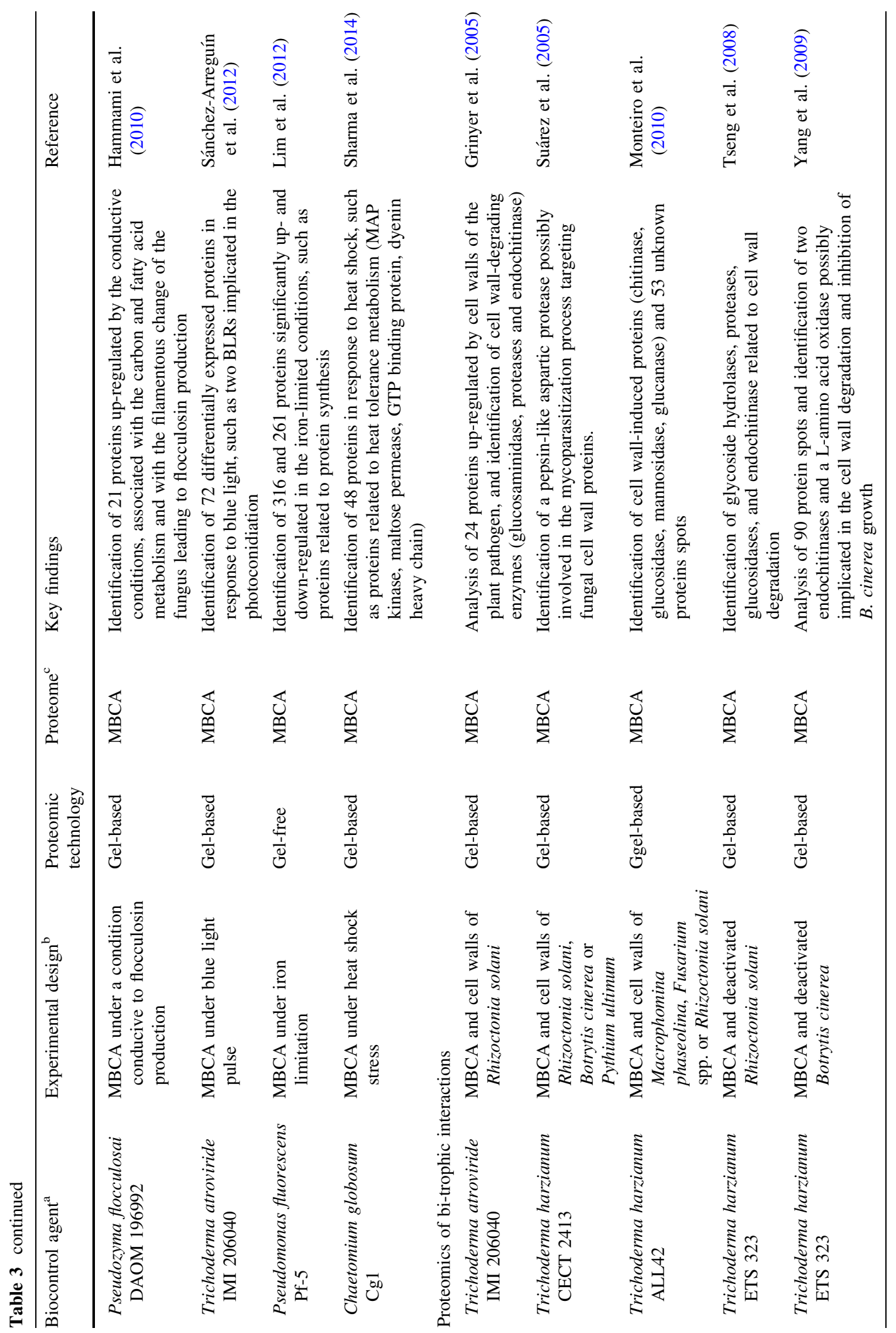




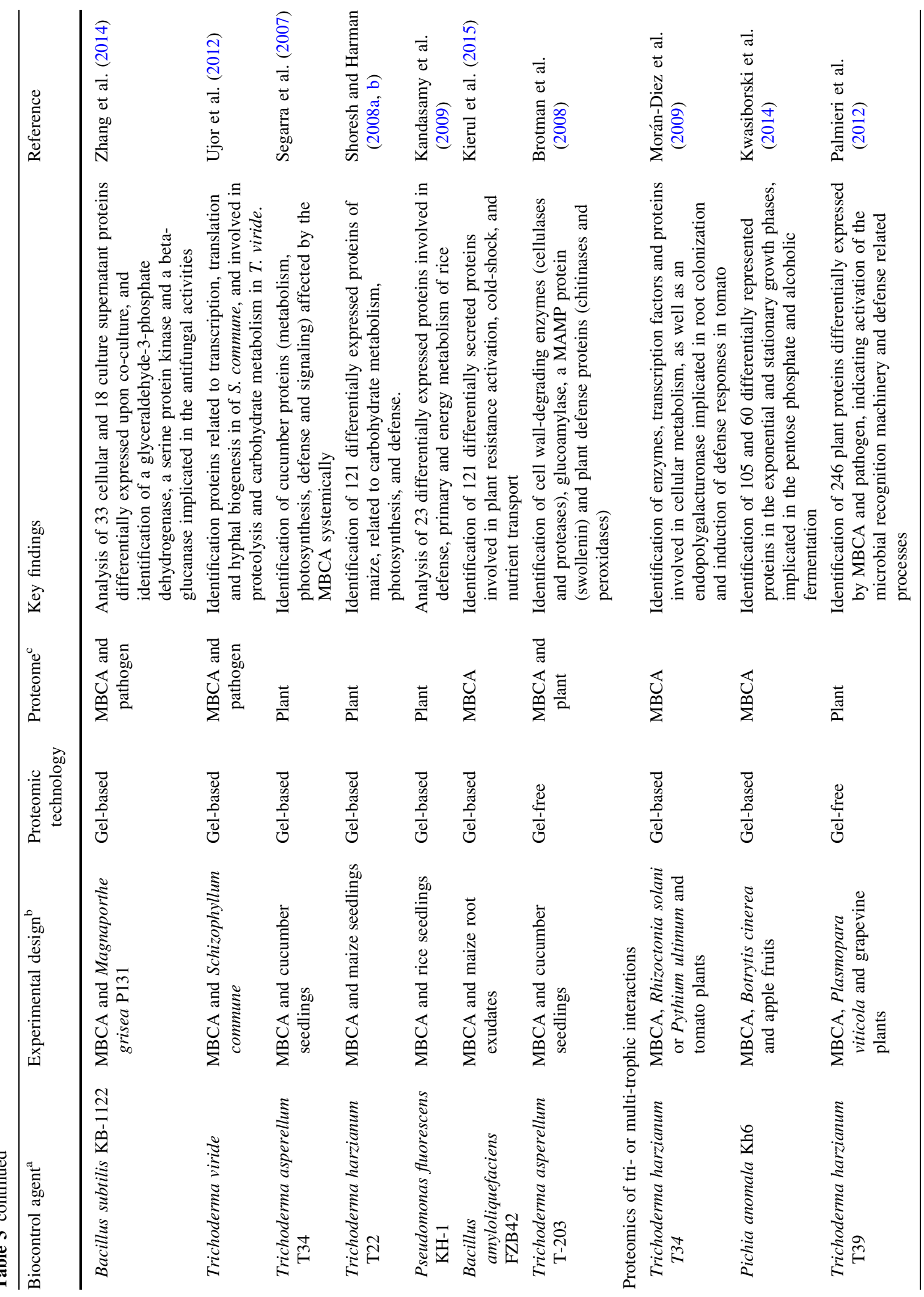




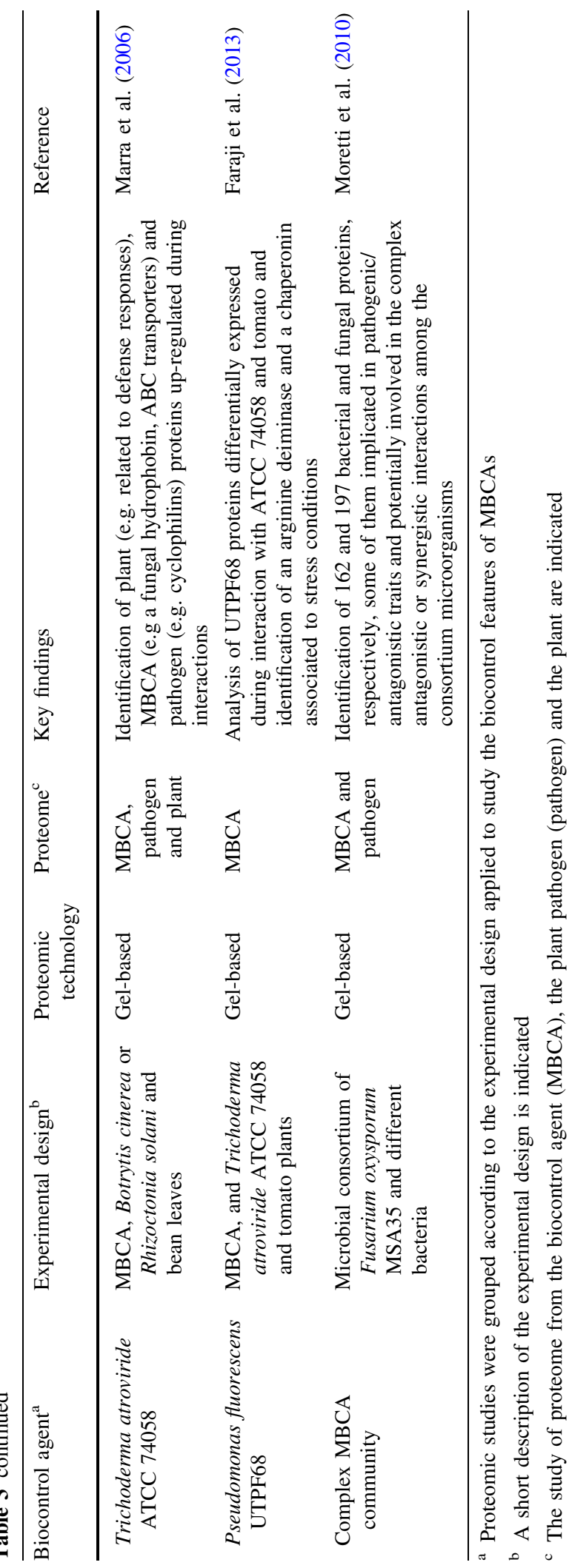


biotechnological value. The design of proteome studies of an MBCA has several similarities with the design of a transcriptome study: the proteome can be compared under contrasting in vitro conditions or during bi-trophic and tri-trophic interactions.

Proteomic analysis of MBCAs has advanced significantly in the last few years (Table 3). As regards bacteria, proteomic studies of Bacillus subtilis IS58, even though it was not used as a BCA, were the first to be addressed (Bernhardt et al. 1997; Schmid et al. 1997). As regards filamentous fungi, proteomic fingerprinting of biocontrol strains belonging to the Trichoderma genus was the first to become available (Grinyer et al. 2004a, b), and a review of Trichoderma sp. proteomes highlighted the main steps in the characterization of these MBCAs (Lorito et al. 2010).

Specific aspects of the MBCA metabolism related to the biocontrol of pathogens can be explored by proteomic analysis. For example, $P$. flocculosa is able to colonize powdery mildew colonies and this ability is facilitated by the release of an antifungal glycolipid (flocculosin). Proteome studies of $P$. flocculosa DAOM 196992 suggested that flocculosin synthesis is elicited as response to specific stress or limiting conditions (Hammami et al. 2010).

Comparison of the proteome expressed by an MBCA strain and a non-effective strain has been carried out for bacterial MBCAs: B. subtilis strains KB-1122 (Zhang et al. 2009), B. subtilis strain FZB24 (Baysal et al. 2013), B. amyloliquefaciens strain KPS46 (Buensanteai et al. 2008) and P. chlororaphis strain PA23 (Kwasiborski et al. 2014). Two comparison models have been studied: proteome analysis of an MBCA strain and a natural strain exhibiting low biocontrol activity (Baysal et al. 2013; Zhang et al. 2009) and proteome analysis between the MBCA strain and an impaired mutant without biocontrol activity (Buensanteai et al. 2008; Kwasiborski et al. 2014). These studies identified differentially expressed proteins related to expected biocontrol functions (e.g. lytic enzymes and lipopeptide production) and a large group of proteins with unknown functions (Kwasiborski et al. 2014) possibly involved in the biocontrol activities.

Differential proteomics experiments involved analysis of the MBCA proteome during the bi-trophic interaction of the MBCA from the Trichoderma genus (Cheng et al. 2012; Grinyer et al. 2005; Monteiro et al. 2010; Suárez et al. 2005; Tseng et al. 2008; Ujor et al.
2012; Yang et al. 2009) and B. subtilis (Zhang et al. 2014) with the plant pathogen. The protein abundance of cell wall degrading enzymes was significantly increased by the MBCA during the interaction with the plant pathogen, but the proteomic response was related to the origin of the pathogen cell walls (Suárez et al. 2005). In the case of co-culture between the MBCA and the plant pathogen, proteomic analysis identified cellular and secreted proteins involved in the $B$. subtilis KB-1122 and $M$. grisea $\mathrm{P} 131$ interaction (Zhang et al. 2014), and defense processes activated by the plant pathogen Schizophyllum commune in response to $T$. viride parasitization (Ujor et al. 2012). Proteomics can also be used to study antagonistic microbial consortia presenting biocontrol properties, such as the F. oxysporum MSA35 (Moretti et al. 2010), or interactions between two MBCAs, such as $P$. fluorescens UTPF68 and T. atroviride ATCC 74058 (Faraji et al. 2013), to highlight syntrophic relations and compatibility issues during combined applications.

Biocontrol mechanisms are also mediated by the activation of plant resistance, and proteomic studies of MBCA-plant interactions have focused on the identification of microbe-associated molecular patterns (MAMPs) or plant regulators responsible for resistance activation. Some MAMPs were identified in MBCA proteomes, such as cyclophilin (Grinyer et al. 2004a, b), swollenin (Brotman et al. 2008), endopolygalacturonase (Morán-Diez et al. 2009) and flagellin proteins (Kierul et al. 2015). Changes in the plant proteome caused by MBCA application have been reported for cucumber (Brotman et al. 2008; Segarra et al. 2007), maize (Shoresh and Harman 2008a, b), and rice (Kandasamy et al. 2009).

More complex models, corresponding to the tritrophic interactions have been less studied but do have enormous potential to provide insights into the multispecies cross-talk in microbe-microbe and plantmicrobe communications. For example, complex changes in the T. atroviride ATCC 74058 proteome were found during multi-player interactions, and specific changes in protein abundances were found in response to $B$. cinerea or $R$. solani, suggesting a sophisticated modulation of the MBCA proteome (Marra et al. 2006). Moreover, the MBCA altered the expression of several disease-related proteins of bean (Marra et al. 2006) and grapevine (Palmieri et al. 2012). However, proteomic analysis of multi-trophic 
interaction can be complicated to analyze, due to the presence of similar proteins from various species that could increase the complexity of species assignment. These limitations can be partially overcome by genome sequencing and by developing in situ models that allow for nutrient exchanges and limit the contaminations by the plant components (Kwasiborski et al. 2014).

Proteomic studies also have great potential for optimization of the industrial production of MBCAs. For example, a proteomic analysis of the conidiation process of T. atroviride IMI 206040 identified transcription factors responsible for the photoconidiation process (Sánchez-Arreguín et al. 2012). Moreover, proteomic approaches carried out on MBCAs identified potential elicitors of plant defense mechanisms and plant growth stimulation (Hermosa et al. 2010). Although many proteins related to the biocontrol activities are well characterized, a relevant fraction of the identified protein remains unidentified in most of the proteomic studies (Kwasiborski et al. 2014; Monteiro et al. 2010; Palmieri et al. 2012; Sharma et al. 2014), suggesting that further investigations are required. Biocontrol proteins can be then used for biotechnological industrial applications, such as their production in bioreactors and for their selective purification (e.g. bioactive plant protection molecules). Since the growth and activity of MBCAs is affected by several factors, the use of the purified active ingredients (e.g. resistance inducers, toxin, enzymes) could be more stable and could give more reproducible results than those achieved with the use of whole microorganisms. Identification of protein effectors of MBCAs and post-translational modification of key receptors are particularly important to understand modulation processes and possible limitations for biocontrol mechanisms and to select new MBCAs.

Progress has been made in the field of microbial proteomics thanks to developments in sample preparation, high resolution separation techniques, high performance mass spectrometers and software for protein identification and quantification (Armengaud 2013; Otto et al. 2014, 2012; Oudenhove and Devreese 2013). However, there still exist different technical challenges and limitations since protein separation and analysis are inherently skill-based and are difficult to automate. The bias has decreased significantly as the numbers of observed peptides per protein have increased (Daly et al. 2008), highlighting advantages of large proteomic data developed with the gel-free technologies. However, large and expensive proteomic facilities, sophisticated bioinformatics analyses and robust statistical tools are required for the new proteomic technologies. As for the NGS technologies, cost reductions and user-friendly analysis tools are expected in the near future.

\section{Conclusions: MBCAs in the post-omic area}

The exponential development of omic technologies is impacting biocontrol research. Technological and bioinformatic improvements have significantly increased our knowledge of MBCAs and their properties. It is noteworthy that NGS technologies are also yielding better understanding of their interactions with the plant microbial communities (Massart et al. 2015). Genome sequencing of MBCAs is likely to become one of the first steps in its characterization. The genome sequence can provide a holistic backbone to support further studies whatever the technologies and methodologies used.

Whichever omic approach is used (transcriptomic, proteomic, metabolomic), MBCA properties should preferably be identified in advance by traditional means. It is recommended that hypotheses, based on microbiological, biochemical and microscopic analysis, should be already in place on the mode of action of the MBCAs. With this preliminary knowledge a more appropriate experimental model can be applied to obtain omic data. The experimental model (with the comparison of conditions, timing of sampling and sample processing etc.) is key to the success of the approach. Omic data analysis can also specifically target those functions or pathways that are suspected to play a role. Data analysis is now a bottleneck for an omic approach. The complexity of data analysis warrants thorough training of the biocontrol researcher and/or close collaboration with bioinformatics laboratories. After rigorous bioinformatics analysis, extracting relevant information from the data (i.e. biological interpretation of the generated information) is essential to avoid the recurrent comments on the omics results: "so what?". The relevance of omics results to practical improvement of biocontrol properties of the MBCA depends on biological interpretation and on an appropriately designed experimental 
scheme. So far, the omic approaches have been carried out individually or sequentially. The integration of multi-scale types of biological information is capable of delivering an integrated and holistic approach to capture the temporal and spatial dynamics of the biological model but remains very challenging.

The omics approach then helps us to grasp the complexity of MBCA's modes of action (i.e. the sequence of events, the influence of environmental factors, etc.) and adds weight to the hypothesis of their implication in efficacy against the pathogen. However, such implication should be further explored with genetic engineering tools such as gene disruption or over-expression to demonstrate how the suggested action plays out.

Acknowledgments The authors apologize to the scientists that are not cited because of space limitation. Michele Perazzolli and Ilaria Pertot were partially supported by the INNOVA project (Subprogramme: FP7-PEOPLE-2012-IAPP, Project reference: 324416$)$.

\section{References}

Adomas A, Eklund M, Johansson M, Asiegbu FO (2006) Identification and analysis of differentially expressed cDNAs during nonself-competitive interaction between Phlebiopsis gigantea and Heterobasidion parviporum. FEMS Microbiol Ecol 57:26-39

Aegerter BJ, Gordon TR (2006) Rates of pitch canker induced seedling mortality among Pinus radiata families varying in levels of genetic resistance to Gibberella circinata (anamorph Fusarium circinatum). For Ecol Manag 235:14-17

Alfano G, Ivey ML, Cakir C, Bos JI, Miller SA, Madden LV, Kamoun S, Hoitink HA (2007) Systemic modulation of gene expression in tomato by Trichoderma hamatum 382 . Phytopathology 97:429-437

Armengaud J (2013) Microbiology and proteomics, getting the best of both worlds! Environ Microbiol 15:12-23

Bachmann B, van Lanen S, Baltz R (2014) Microbial genome mining for accelerated natural products discovery: is a renaissance in the making? J Ind Microbiol Biotechnol 41:175-184

Barret M, Frey-Klett P, Boutin M, Guillerm-Erckelboudt AY, Martin F, Guillot L, Sarniguet A (2009a) The plant pathogenic fungus Gaeumannomyces graminis var. tritici improves bacterial growth and triggers early gene regulations in the biocontrol strain Pseudomonas fluorescens Pf29Arp. New Phytol 181:435-447

Barret M, Frey-Klett P, Guillerm-Erckelboudt AY, Boutin M, Guernec G, Sarniguet A (2009b) Effect of wheat roots infected with the pathogenic fungus Gaeumannomyces graminis var. tritici on gene expression of the biocontrol bacterium Pseudomonas fluorescens Pf29Arp. Mol Plant Microbe Interact 22:1611-1623
Baysal Ö, Lai D, Xu HH, Siragusa M, Çalışkan M, Carimi F, da Silva JAT, Tör M (2013) A proteomic approach provides new insights into the control of soil-borne plant pathogens by Bacillus species. PLoS ONE 8:e53182

Bernhardt J, Völker U, Völker A, Antelmann H, Schmid R, Mach H, Hecker M (1997) Specific and general stress proteins in Bacillus subtilis-a two-dimensional protein electrophoresis study. Microbiology 143:999-1017

Brotman Y, Briff E, Viterbo A, Chet I (2008) Role of swollenin, an expansin-like protein from Trichoderma, in plant root colonization. Plant Physiol 147:779-789

Brown SD, Utturkar SM, Klingeman DM, Johnson CM, Martin SL, Land ML, Lu TS, Schadt CW, Doktycz MJ, Pelletiera DA (2012) Twenty-one genome sequences from pseudomonas species and 19 genome sequences from diverse bacteria isolated from the rhizosphere and endosphere of Populus deltoides. J Bacteriol 194:5991-5993

Buensanteai N, Yuen GY, Prathuangwong S (2008) The biocontrol bacterium Bacillus amyloliquefaciens KPS46 produces auxin, surfactin and extracellular proteins for enhanced growth of soybean plant. Thai J Agric Sci 41:111-116

Challis GL (2008) Mining microbial genomes for new natural products and biosynthetic pathways. Microbiology 154:1555-1569

Chen XH, Koumoutsi A, Scholz R, Eisenreich A, Schneider K, Heinemeyer I, Morgenstern B, Voss B, Hess WR, Reva O, Junge H, Voigt B, Jungblut PR, Vater J, Süssmuth R, Liesegang H, Strittmatter A, Gottschalk G, Borriss R (2007) Comparative analysis of the complete genome sequence of the plant growth-promoting bacterium Bacillus amyloliquefaciens FZB42. Nat Biotechnol 25:1007-1014

Chen W, Yunsheng W, Dingjun L, Lin L, Qiming X, Qingming Z (2012) Draft genome sequence of Brevibacillus brevis strain X23, a biocontrol agent against bacterial wilt. J Bacteriol 194:6634-6635

Cheng C-H, Yang C-A, Peng K-C (2012) Antagonism of Trichoderma harzianum ETS 323 on Botrytis cinerea mycelium in culture conditions. Phytopathology 102:1054-1063

Czajkowski R, van der Wolfa JM (2012) Draft genome sequence of the biocontrol strain Serratia plymuthica A30, isolated from rotting potato tuber tissue. J Bacteriol 194:6999-7000

Daly DS, Anderson KK, Panisko EA, Purvine SO, Fang R, Monroe ME, Baker SE (2008) Mixed-effects statistical model for comparative LC-MS proteomics studies. J Proteome Res 7:1209-1217

Daval S, Lebreton L, Gazengel K, Boutin M, Guillerm-Erckelboudt AY, Sarniguet A (2011) The biocontrol bacterium Pseudomonas fluorescens Pf29Arp strain affects the pathogenesis-related gene expression of the take-all fungus Gaeumannomyces graminis var. tritici on wheat roots. Mol Plant Pathol 12:839-854

De Las RJ, Aibar S, Roson B (2014) Gene expression analysis and profiling of microarrays data and RNA-sequencing data. In: Cifuentes A, Simó C, Virginia GC (eds) Comprehensive analytical chemistry, vol 63. Elsevier, Oxford, UK, pp 355-384

Eyiwumi Olorunleke F, Phuong Kieu N, Höfte M (2015) Recent advances in pseudomonas biocontrol pp. In: Murillo J, Vinatzer B, Jackson R, Arnold D (eds) Bacteria-plant 
interactions: advanced research and future trends. Caister Academic Press, Wymondham, UK, pp 167-198

Faraji M, Ahmadzadeh M, Behboudi K, Okhovvat SM, Ruocco M, Lorito M, Rezaei-Tavirani M, Zali H (2013) Study of proteome pattern of Pseudomonas fluorescens strain UTPF68 in interaction with Trichoderma atroviride strain P1 and tomato. J Paramed Sci 4:30-44

Feng DX, Tasset C, Hanemian M, Barlet X, Hu J, Trémousaygue D, Deslandes L, Marco Y (2012) Biological control of bacterial wilt in Arabidopsis thaliana involves abscissic acid signalling. New Phytol 194:1035-1045

Gil C, Monteoliva L (2014) Trends in microbial proteomics. J Proteomics 97:1-2

Grevesse C, Lepoivre P, Jijakli MH (2003) Characterization of the exoglucanase-encoding gene PaEXG2 and study of its role in the biocontrol activity of Pichia anomala strain K. Phytopathology 93:1145-1152

Grinyer J, McKay M, Herbert B, Nevalainen H (2004a) Fungal proteomics: mapping the mitochondrial proteins of a Trichoderma harzianum strain applied for biological control. Curr Genet 45:170-175

Grinyer J, McKay M, Nevalainen H, Herbert B (2004b) Fungal proteomics: initial mapping of biological control strain Trichoderma harzianum. Curr Genet 45:163-169

Grinyer J, Hunt S, McKay M, Herbert B, Nevalainen H (2005) Proteomic response of the biological control fungus Trichoderma atroviride to growth on the cell walls of Rhizoctonia solani. Curr Genet 47:381-388

Grinyer J, Kautto L, Traini M, Willows R, Te'o J, Bergquist P, Nevalainen H (2007) Proteome mapping of the Trichoderma reesei $20 \mathrm{~S}$ proteasome. Curr Genet 51:79-88

Hammami W, Chain F, Michaud D, Belanger R (2010) Proteomic analysis of the metabolic adaptation of the biocontrol agent Pseudozyma flocculosa leading to glycolipid production. Proteome Sci 8:7

Hao K, He P, Blom J, Rueckert C, Mao Z, Wu Y, He Y, Borriss R (2012) The genome of plant growth-promoting Bacillus amyloliquefaciens subsp. plantarum Strain YAU B9601Y2 contains a gene cluster for mersacidin synthesis. J Bacteriol 194:3264-3265

Hassan KA, Johnson A, Shaffer BT, Ren Q, Kidarsa TA, Elbourne LDH, Hartney S, Duboy R, Goebel NC, Zabriskie TM, Paulsen IT, Lope JE (2010) Inactivation of the GacA response regulator in Pseudomonas fluorescens Pf-5 has far-reaching transcriptomic consequences. Environ Microbiol 12:899-915

Helsens K., Colaert N, Barsnes H, Muth T, Flikka K, Staes A, Timmerman E, Wortelkamp S, Sickmann A, Vandekerckhove J, Gevaert K, Martens L (2010) Ms_lims, a simple yet powerful open source laboratory information management system for MS-driven proteomics. Proteomics 10:1261-1264

Hermosa RL, Woo S, Lorito M, Monte E (2010) Proteomic approaches to understand Trichoderma biocontrol mechanisms and plant interactions. Curr Proteomics 7:298-305

Hershkovitz V, Ben-Dayan C, Raphael G, Pasmanik-Chor M, Liu J, Belausov E, Aly R, Wisniewski M, Droby S (2012) Global changes in gene expression of grapefruit peel tissue in response to the yeast biocontrol agent Metschnikowia fructicola. Mol Plant Pathol 13:338-349

Hershkovitz V, Sela N, Taha-Salaime L, Liu J, Rafael G, Kessler C, Aly R, Levy M, Wisniewski M, Droby S (2013) De-novo assembly and characterization of the transcriptome of Metschnikowia fructicola reveals differences in gene expression following interaction with Penicillium digitatum and grapefruit peel. BMC Genom 14:168

Illakkiam D, Shankar M, Ponraj P, Rajendhran J, Gunasekaran P (2014) Genome sequencing of a mung bean plant growth promoting strain of $P$. aeruginosa with biocontrol ability. Int J Genomics. doi:10.1155/2014/123058

Jiang F, Zheng X, Chen J (2009) Microarray analysis of gene expression profile induced by the biocontrol yeast Cryptococcus laurentii in cherry tomato fruit. Gene 430:12-16

Jijakli MH, Lepoivre P (1998) Characterization of an exo- $\beta$ - $1,3-$ glucanase produced by Pichia anomala strain K, antagonist of Botrytis cinerea on apples. Phytopathology 88:335-343

Kandasamy S, Loganathan K, Muthuraj R, Duraisamy S, Seetharaman S, Thiruvengadam R, Ponnusamy B, Ramasamy S (2009) Understanding the molecular basis of plant growth promotional effect of Pseudomonas fluorescens on rice through protein profiling. Proteome Sci 7:1-8

Kanehisa M, Goto S, Kawashima S, Nakaya A (2002) The KEGG databases at GenomeNet. Nucleic Acids Res 30:42-46

Kierul K, Voigt B, Albrecht D, Chen XH, Carvalhais LC, Borriss $R$ (2015) Influence of root exudates on the extracellular proteome of the plant growth-promoting bacterium Bacillus amyloliquefaciens FZB42. Microbiology 161:131-147

Kim HJ, Park JY, Han SH, Lee JH, Rong X, McSpadden Gardener BB, Park SK, Kim YC (2011) Draft genome sequence of the biocontrol bacterium Chromobacterium sp. strain C-61. J Bacteriol 193:6803-6804

Klaponski N, Selin C, Duke K, Spicer V, Fernando D, Belmonte M, de Kievit T (2014) The requirement for the LysR-type regulator PtrA for Pseudomonas chlororaphis PA23 biocontrol revealed through proteomic and phenotypic analysis. BMC Microbiol 14:94

Knief C (2014) Analysis of plant microbe interactions in the era of next generation sequencing technologies. Front Plant Sci. 5:216

Kubicek CP, Herrera-Estrella A, Seidl-Seiboth V, Martinez DA, Druzhinina IS, Thon M, Zeilinger S, Casas-Flores S, Horwitz BA, Mukherjee PK, Mukherjee M, Kredics L, Alcaraz LD, Aerts A, Antal Z, Atanasova L, CervantesBadillo MG, Challacombe J, Chertkov O, McCluskey K, Coulpier F, Deshpande N, von Döhren H, Ebbole DJ, Esquivel-Naranjo EU, Fekete E, Flipphi M, Glaser F, Gómez-Rodríguez EY, Gruber S, Han C, Henrissat B, Hermosa R, Hernández-Oñate M, Karaffa L, Kosti I, Le Crom S, Lindquist E, Lucas S, Lübeck M, Lübeck PS, Margeot A, Metz B, Misra M, Nevalainen H, Omann M, Packer N, Perrone G, Uresti-Rivera EE, Salamov A, Schmoll M, Seiboth B, Shapiro H, Sukno S, Tamayo-Ramos JA, Tisch D, Wiest A, Wilkinson HH, Zhang M, Coutinho PM, Kenerley CM, Monte E, Baker SE, Grigoriev IV (2011) Comparative genome sequence analysis underscores mycoparasitism as the ancestral life style of Trichoderma. Genome Biol 12:R40

Kwasiborski A, Bajji M, Renaut J, Delaplace P, Jijakli MH (2014) Identification of metabolic pathways expressed by Pichia anomala Kh6 in the presence of the pathogen Botrytis cinerea on apple: new possible targets for biocontrol improvement. PLoS ONE 9:e91434 
Lee SY, Kim BY, Ahn JH, Song J, Seol YJ, Kim WG, Weon HY (2012) Draft genome sequence of the biocontrol bacterium Bacillus amyloliquefaciens strain M27. J Bacteriol 194:6934-6935

Lefebvre F, Joly DL, Labbé C, Teichmann B, Linning R, Belzile F, Bakkeren G, Bélanger RR (2013) The transition from a phytopathogenic smut ancestor to an anamorphic biocontrol agent deciphered by comparative whole-genome analysis. Plant Cell 25:1946-1959

Lim CK, Hassan KA, Tetu SG, Loper JE, Paulsen IT (2012) The effect of iron limitation on the transcriptome and proteome of Pseudomonas fluorescens Pf-5. PLoS ONE 7(6):e39139

Lim JA, Lee DH, Kim BY, Heu S (2014) Draft genome sequence of Pantoea agglomerans R190, a producer of antibiotics against phytopathogens and foodborne pathogens. J Biotechnol 188:7-8

Liu PG, Yang Q (2005) Identification of genes with a biocontrol function in Trichoderma harzianum mycelium using the expressed sequence tag approach. Res Microbiol 156:416-423

Liu J, Zhou Q, Ibrahim M, Liu H, Jin G, Zhu B, Xie G (2012) Genome sequence of the biocontrol agent Microbacterium barkeri strain 2011-R4. J Bacteriol 194:6666-6667

Loper JE, Hassan KA, Mavrodi DV, Davis EW, Lim CK, Shaffer BT, Elbourne LD, Stockwell VO, Hartney SL, Breakwell K, Henkels MD, Tetu SG, Rangel LI, Kidarsa TA, Wilson NL, van de Mortel JE, Song C, Blumhagen R, Radune D, Hostetler JB, Brinkac LM, Durkin AS, Kluepfel DA, Wechter WP, Anderson AJ, Kim YC, Pierson LS III, Pierson EA, Lindow SE, Kobayashi DY, Raaijmakers JM, Weller DM, Thomashow LS, Allen AE, Paulsen IT (2012) Comparative genomics of plant-associated Pseudomonas spp.: insights into diversity and inheritance of traits involved in multitrophic interactions. PLoS Genet 8:e1002784

Lorito M, Woo SL, Harman GE, Monte E (2010) Translational research on Trichoderma: from 'omics to the field. Annu Rev Phytopathol 48:395-417

Marra R, Ambrosino P, Carbone V, Vinale F, Woo S, Ruocco M, Ciliento R, Lanzuise S, Ferraioli S, Soriente I, Gigante S, Turrà D, Fogliano V, Scala F, Lorito M (2006) Study of the three-way interaction between Trichoderma atroviride, plant and fungal pathogens by using a proteomic approach. Curr Genet 50:307-321

Martinez-Garcia P, Ruano-Rosa D, Schiliro E, Prieto P, Ramos C, Rodriguez-Palenzuela P, Mercado-Blanco J (2015) Complete genome sequence of Pseudomonas fluorescens strain PICF7, an indigenous root endophyte from olive (Olea europaea L.) and effective biocontrol agent against Verticillium dahliae. Stand Genomic Sci 10:10

Massart S, Jijakli MH (2006) Identification of differentially expressed genes by cDNA-amplified fragment length polymorphism in the biocontrol agent Pichia anomala (strain Kh5). Phytopathology 96:80-86

Massart S, Jijakli HM (2007) Use of molecular techniques to elucidate the mechanisms of action of fungal biocontrol agents: a review. J Microbiol Methods 69:229-241

Massart S, Martinez-Medina M, Jijakli MH (2015) Biological control in the microbiome era: challenges and opportunities. Biol control 89: 98-108

Mathimaran N, Srivastava R, Wiemken A, Sharma AK, Boller T (2012) Genome sequences of two plant growth-promoting fluorescent Pseudomonas strains, R62 and R81. J Bacteriol 194:3272-3273

McGettigan PA (2013) Transcriptomics in the RNA-seq era. Curr Opin Chem Biol 17:4-11

Mesuere B, Devreese B, Debyser G, Aerts M, Vandamme P, Dawyndt P (2012) Unipept: tryptic peptide-based biodiversity analysis of metaproteome samples. J Proteome Res 11:5773-5780

Mgbeahuruike AC, Kohler A, Asiegbu FO (2013) Expression analysis of the impact of culture filtrates from the biocontrol agent, Phlebiopsis gigantea on the conifer pathogen, Heterobasidion annosum s.s. transcriptome. Microb Ecol 66:669-681

Monteiro V, Nascimento Silva R, Steindorff A, Costa F, Noronha E, Ricart C, Sousa M, Vainstein M, Ulhoa C (2010) New insights in Trichoderma harzianum antagonism of fungal plant pathogens by secreted protein analysis. Curr Microbiol 61:298-305

Montero-Barrientos M, Hermosa R, Cardoza RE, Gutiérrez S, Monte E (2011) Functional analysis of the Trichoderma harzianum nox 1 gene, encoding an NADPH oxidase, relates production of reactive oxygen species to specific biocontrol activity against Pythium ultimum. Appl Environ Microbiol 77:3009-3016

Morán-Diez E, Hermosa R, Ambrosino P, Cardoza RE, Gutiérrez S, Lorito M, Monte E (2009) The ThPG1 endopolygalacturonase is required for the Trichoderma harzianum-plant beneficial interaction. Mol Plant Microbe Interact 22:1021-1031

Morán-Diez E, Rubio B, Domínguez S, Hermosa R, Monte E, Nicolás C (2012) Transcriptomic response of Arabidopsis thaliana after $24 \mathrm{~h}$ incubation with the biocontrol fungus Trichoderma harzianum. J Plant Physiol 169:614-620

Moretti M, Grunau A, Minerdi D, Gehrig P, Roschitzki B, Eberl L, Garibaldi A, Gullino ML, Riedel K (2010) A proteomics approach to study synergistic and antagonistic interactions of the fungal-bacterial consortium Fusarium oxysporum wild-type MSA 35. Proteomics 10:3292-3320

Mukherjee PK, Horwitz BA, Herrera-Estrella A, Schmoll M, Kenerley CM (2013) Trichoderma research in the genome era. Annu Rev Phytopathol 51:105-129

Niu B, Rueckert C, Blom J, Wang Q, Borriss R (2011) The genome of the plant growth-promoting rhizobacterium Paenibacillus polymyxa $\mathrm{M}-1$ contains nine sites dedicated to nonribosomal synthesis of lipopeptides and polyketides. J Bacteriol 193:5862-5863

Nookaew I, Papini M, Pornputtpong N, Scalcinati G, Fagerberg L, Uhlén M, Nielsen J (2012) A comprehensive comparison of RNA-Seq-based transcriptome analysis from reads to differential gene expression and cross-comparison with microarrays: a case study in Saccharomyces cerevisiae. Nucleic Acids Res 40:10084-10097

Okubara PA, Call DR, Kwak YS, Skinner DZ (2010) Induction of defense gene homologues in wheat roots during interactions with Pseudomonas fluorescens. Biol Control 55:118-125

Otto A, Bernhardt J, Hecker M, Becher D (2012) Global relative and absolute quantitation in microbial proteomics. Curr Opin Microbiol 15:364-372

Otto A, Becher D, Schmidt F (2014) Quantitative proteomics in the field of microbiology. Proteomics 14:547-565 
Oudenhove L, Devreese B (2013) A review on recent developments in mass spectrometry instrumentation and quantitative tools advancing bacterial proteomics. Appl Microbiol Biotechnol 97:4749-4762

Palmieri MC, Perazzolli M, Matafora V, Moretto M, Bachi A, Pertot I (2012) Proteomic analysis of grapevine resistance induced by Trichoderma harzianum T39 reveals specific defence pathways activated against downy mildew. J Exp Bot 63:6237-6251

Park JY, Han SH, Lee JH, Han YS, Lee YS, Rong X, McSpadden Gardener BB, Park HS, Kim YC (2011) Draft genome sequence of the biocontrol bacterium Pseudomonas putida $\mathrm{B} 001$, an oligotrophic bacterium that induces systemic resistance to plant diseases. J Bacteriol 193:6795-6796

Paul D, Dineshkumar N, Nair S (2006) Proteomics of a plant growth-promoting rhizobacterium, Pseudomonas fluorescens MSP-393, subjected to salt shock. World J Microbiol Biotechnol 22:369-374

Paulsen IT, Press CM, Ravel J, Kobayashi DY, Myers GSA, Mavrodi DV, DeBoy RT, Seshadri R, Ren Q, Madupu R, Dodson RJ, Durkin AS, Brinkac LM, Daugherty SC, Sullivan SA, Rosovitz MJ, Gwinn ML, Zhou L, Schneider DJ, Cartinhour SW, Nelson WC, Weidman J, Watkins K, Tran K, Khouri H, Pierson EA, Pierson LS 3rd, Thomashow LS, Loper JE (2005) Complete genome sequence of the plant commensal Pseudomonas fluorescens Pf-5. Nat Biotechnol 23:873-878

Perazzolli M, Moretto M, Fontana P, Ferrarini A, Velasco R, Moser C, Delledonne M, Pertot I (2012) Downy mildew resistance induced by Trichoderma harzianum $\mathrm{T} 39$ in susceptible grapevines partially mimics transcriptional changes of resistant genotypes. BMC Genom 13:660

Puopolo G, Cimmino A, Palmieri MC, Giovannini O, Evidente A, Pertot I (2014) Lysobacter capsici AZ78 produces cyclo(L-Pro-L-Tyr), a 2,5-diketopiperazine with toxic activity against sporangia of Phytophthora infestans and Plasmopara viticola. J Appl Microbiol 117:1168-1180

Redondo-Nieto M, Barret M, Morrissey J, Germaine K, Martínez-Granero F, Barahona E, Navazo A, Sánchez-Contreras M, Moynihan JA, Muriel C, Dowling D, O'Gara F, Martín M, Rivilla R (2013) Genome sequence reveals that Pseudomonas fluorescens F113 possesses a large and diverse array of systems for rhizosphere function and host interaction. BMC Genom 14:54

Reithner B, Ibarra-Laclette E, Mach RL, Herrera-Estrella A (2011) Identification of mycoparasitism-related genes in Trichoderma atroviride. Appl Environ Microbiol 77:4361-4370

Rong X, Gurel FB, Meulia T, Gardener BBM (2012a) Draft genome sequences of the biocontrol bacterium Mitsuaria sp. strain H24L5A. J Bacteriol 194:734-735

Rong X, Gurel FB, Meulia T, McSpadden Gardener BB (2012b) Draft genome sequences of the Pseudomonas fluorescens biocontrol strains Wayne1R and Wood1R. J Bacteriol 194:724-725

Rubio M, Quijada NM, Pérez E, Domínguez S, Monte E, Hermosa R (2014) Identifying beneficial qualities of Trichoderma parareesei for plants. Appl Environ Microbiol 80:1864-1873

Sánchez-Arreguín A, Pérez-Martínez AS, Herrera-Estrella A (2012) Proteomic analysis of Trichoderma atroviride reveals independent roles for transcription factors BLR-1 and BLR-2 in light and darkness. Eukaryot Cell 11:30-41

Schmid R, Bernhardt J, Antelmann H, Völker A, Mach H, Völker U, Hecker M (1997) Identification of vegetative proteins for a two-dimensional protein index of Bacillus subtilis. Microbiology 143:991-998

Segarra G, Casanova E, Bellido D, Odena MA, Oliveira E, Trillas I (2007) Proteome, salicylic acid, and jasmonic acid changes in cucumber plants inoculated with Trichoderma asperellum strain T34. Proteomics 7:3943-3952

Seidl V, Marchetti M, Schandl R, Allmaier G, Kubicek CP (2006) Epl1, the major secreted protein of Hypocrea atroviridis on glucose, is a member of a strongly conserved protein family comprising plant defense response elicitors. FEBS J 273:4346-4359

Seidl V, Song L, Lindquist E, Gruber S, Koptchinskiy A, Zeilinger S, Schmoll M, Martínez P, Sun J, Grigoriev I, Herrera-Estrella A, Baker SE, Kubicek CP (2009) Transcriptomic response of the mycoparasitic fungus Trichoderma atroviride to the presence of a fungal prey. BMC Genom 10:567

Sharma S, Aggarwal R, Yadav A, Gupta S (2014) Protein mapping of Chaetomium globosum, a potential biological control agent through proteomics approach. J Plant Biochem Biotechnol 23:284-292

Shen X, Chen M, Hu H, Wang W, Peng H, Xu P, Zhang X (2012) Genome sequence of Pseudomonas chlororaphis GP72, a root-colonizing biocontrol strain. J Bacteriol 194:1269-1270

Shentu XP, Liu WP, Zhan XH, Xu YP, Xu JF, Yu XP, Zhang CX (2014) Transcriptome sequencing and gene expression analysis of Trichoderma brevicompactum under different culture conditions. PLoS ONE 9:e94203

Shoresh M, Harman GE (2008a) The molecular basis of shoot responses of maize seedlings to Trichoderma harzianum T22 inoculation of the root: a proteomic approach. Plant Physiol 147:2147-2163

Shoresh M, Harman GE (2008b) The relationship between increased growth and resistance induced in plants by root colonizing microbes. Plant Signal Behav 3:737-739

Smits THM, Rezzonico F, Kamber T, Goesmann A, Ishimaru CA, Stockwell VO, Frey JE, Duffy B (2010) Genome sequence of the biocontrol agent Pantoea vagans strain C91. J Bacteriol 192:6486-6487

Song JY, Kwak MJ, Lee KY, Kong HG, Kim BK, Kwon SK, Lee SW, Kim JF (2012) Draft genome sequence of the antifungal-producing plant-benefiting bacterium Burkholderia pyrrocinia CH-67. J Bacteriol 194:6649-6650

Studholme DJ, Harris B, Le Cocq K, Winsbury R, Perera V, Ryder L, Ward JL, Beale MH, Thornton CR, Grant M (2013) Investigating the beneficial traits of Trichoderma hamatum GD12 for sustainable agriculture-insights from genomics. Front Plant Sci. 4:258

Suárez MB, Sanz L, Chamorro MI, Rey M, González FJ, Llobell A, Monte E (2005) Proteomic analysis of secreted proteins from Trichoderma harzianum: identification of a fungal cell wall-induced aspartic protease. Fungal Genet Biol 42:924-934

Sun H, Paulin L, Alatalo E, Asiegbu FO (2011) Response of living tissues of Pinus sylvestris to the saprotrophic 
biocontrol fungus Phlebiopsis gigantea. Tree Physiol 31:438-451

Takeuchi K, Noda N, Someya N (2014) Complete genome sequence of the biocontrol strain Pseudomonas protegens Cab57 discovered in Japan reveals strain-specific diversity of this species. PLoS ONE 9:e93683

Tang J, Liu L, Huang X, Li Y, Chen Y, Chen J (2010) Proteomic analysis of Trichoderma atroviride mycelia stressed by organophosphate pesticide dichlorvos. Can J Microbiol 56:121-127

Trushina N, Levin M, Mukherjee PK, Horwitz BA (2013) PacC and $\mathrm{pH}$-dependent transcriptome of the mycotrophic fungus Trichoderma virens. BMC Genom 14:138

Tseng SC, Liu SY, Yang HH, Lo CT, Peng KC (2008) Proteomic study of biocontrol mechanisms of Trichoderma harzianum ETS 323 in response to Rhizoctonia solani. J Agric Food Chem 56:6914-6922

Ujor VC, Peiris DG, Monti M, Kang AS, Clements MO, Hedger JN (2012) Quantitative proteomic analysis of the response of the wood-rot fungus, Schizophyllum commune, to the biocontrol fungus, Trichoderma viride. Lett Appl Microbiol 54:336-343

Vilanova L, Wisniewski M, Norelli J, Viñas I, Torres R, Usall J, Phillips J, Droby S, Teixidó N (2014) Transcriptomic profiling of apple in response to inoculation with a pathogen (Penicillium expansum) and a non-pathogen (Penicillium digitatum). Plant Mol Biol Rep 32:566-583

Viterbo A, Harel M, Chet I (2004) Isolation of two aspartyl proteases from Trichoderma asperellum expressed during colonization of cucumber roots. FEMS Microbiol Lett 238:151-158

Wilkins MR, Sanchez JC, Gooley AA, Appel RD, HumpherySmith I, Hochstrasser DF, Williams KL (1995) Progress with proteome projects: why all proteins expressed by a genome should be identified and how to do it. Biotechnol Genet Eng Rev 13:19-50

Wöhlbrand L, Trautwein K, Rabus R (2013) Proteomic tools for environmental microbiology—a roadmap from sample preparation to protein identification and quantification. Proteomics 13:2700-2730

Wu DQ, Ye J, Ou HY, Wei X, Huang X, He YW, Xu Y (2011) Genomic analysis and temperature-dependent transcriptome profiles of the rhizosphere originating strain Pseudomonas aeruginosa M18. BMC Genom 12:438
Yang HH, Yang SL, Peng KC, Lo CT, Liu SY (2009) Induced proteome of Trichoderma harzianum by Botrytis cinerea. Mycol Res 113:924-932

Zhang CX, Zhao X, Han F, Yang MF, Chen H, Chida T, Shen SH (2009) Comparative proteome analysis of two antagonist Bacillus subtilis strains. J Microbiol Biotechnol 19:351-357

Zhang C, Zhang X, Shen S (2014) Proteome analysis for antifungal effects of Bacillus subtilis KB-1122 on Magnaporthe grisea P131. World J Microbiol Biotechnol 30:1763-1774

Sebastien Massart is working in the biotechnology field from 15 years, alternating public and private sectors. He is now associated professor at University of Liège, Belgium and his research focus is the application of new biotechnologies for a better control of plant pathogens.

Michele Perazzolli is a biotechnologist researcher at Fondazione Edmund Mach, Italy. He has research experience in transcriptomic and proteomic characterization of plant-microbe interactions and biological control processes.

Monica Höfte is a professor in plant pathology since 1997 at Ghent University in Belgium. Her research interests are biological and integrated control of plant pathogens and natural and induced resistance mechanisms against fungi and bacteria.

Ilaria Pertot is senior researcher at Fondazione Edmund Mach with 25 years of experience in plant pathology, plant protection and development of biofungicides. Her main research interest is the use of advanced technologies to improve the efficacy of biofungicides.

M. Haïssam Jijakli is a professor in plant pathology at University of Liège, Belgium and has a 25 years experience in the development of biocontrol methods based on (micro-) organisms and their derivatives to protect plants against phytopathogens. His laboratory has acquired an international recognition in biocontrol using fundamental and practical approaches. 